\title{
Die impak van die teologie van Dirk Postma op die Gereformeerde Hermeneutiek
}

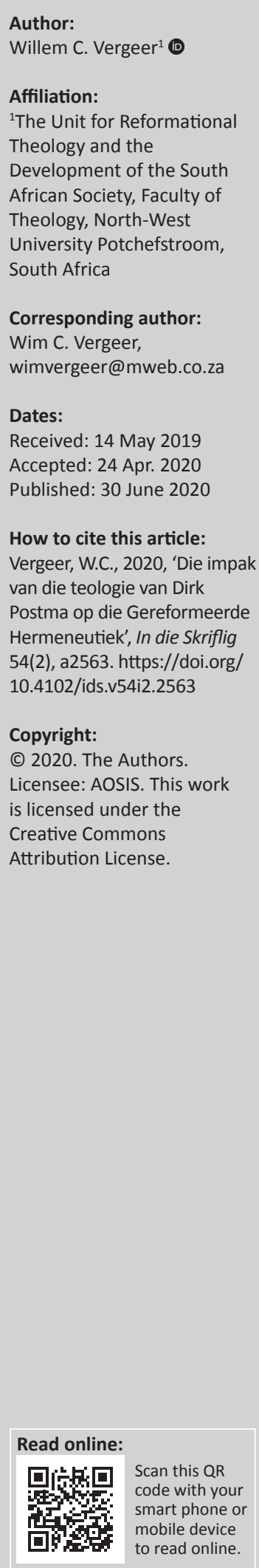

The impact of the theology of Dirk Postma on Reformed Hermeneutics: At the 150th commemoration of the founding of the Theological Seminary of the Reformed Churches of SouthAfrica, this article explores the specific historical origins and characteristics of Reformed Hermeneutics. By determining the rules of exegesis, Reformed Hermeneutics indeed has a fundamental influence on the development of Reformed Theology. The research indicates that the theological views of Dirk Postma lay at the heart of Reformed Hermeneutics. His views can further be traced to those of Aegidius Francken, a product of the Nadere Reformatie. An analysis of two recent publications outlining Reformed Hermeneutics indicates that the same hermeneutical principles that Dirk Postma upheld, still hold sway in Reformed Theology today. These principles are outlined and are put forward as standard for the future development of Reformed Theology.

Keywords: Gereformeerde Hermeneutiek; Dirk Postma; Aegidius Francken; Teologiese Skool Potchefstroom; Teologiese opleiding; Reformed Hermeneutics; Theological Seminary Potchefstroom; Theological education.

\section{Inleiding ${ }^{1}$}

In sy afskeidswoord by die neerlegging van sy amp as teologiese professor sê Jan Lion Cachet (1911):

Ons het begin, die studente was min en swak; die dosente het geen akademiese grade gehad nie, maar ons het begin en die fondamente gegrawe in die hoop dat eenmaal op die fondament ' $n$ tempel vir die wetenskap sou verrys waarvan die hoeksteen sou wees: Gods heilige Woord. (p. 6)

Hierdie uitspraak deur die tweede dosent (naas Dirk Postma) wat aan die Teologiese Skool te Burgersdorp (1869) sou dien, getuig van die groot uitdagings, maar ook van die vaste grond en hoop waarmee die werk aan 'n eie teologiese skool aangepak is.

Wat die gebrek aan akademiese kwalifikasies van die dosente betref, het Cachet nie oordryf nie. Dirk Postma het waarskynlik geen of min skoolopleiding ondergaan en moes na die dood van sy vader as tiener uitspring om die gesin te help onderhou (Van der Vyver 1958:26-29). Na minder as een jaar indiensopleiding by dominee T.F. de Haan ${ }^{2}$ van die Wansweerd kombinasie, is hy in 1840 deur die sinode van die Christelijke Afgescheie Gereformeerde Kerk (CAGK) geëksamineer en tot die bediening toegelaat. Alhoewel hy in 'n groot verskeidenheid vakke ondervra is (waaronder Uitlechkunde), was sy kennis op daardie stadium 'betreklik elementêr' (Van der Vyver 1958:47).

Postma was hiervan terdeë bewus ${ }^{3}$ en het as 'studieuse blikslagersknecht' (Schutte 2009:5) steeds daarna gestreef om homself te verbeter en te bekwaam - veral in die antieke tale en Bybelwetenskappe. Hy het in so 'n mate gevorder, dat sy kennis op hierdie gebied in later jare deur sy studente en selfs sy teenstanders hoog aangeslaan is (Van der Vyver 1958:386-387, 435).

Die drang om kennis - veral teologiese kennis - oor te dra het egter van vroeg af aan in Postma geleef. Volgens Van der Vyfer (1958:39-43) het Postma al voor sy toelating tot die bediening as oefenaar (voorganger en kategeet) in die gemeente van Wanswerd opgetree. Slegs een jaar na sy 1.In hierdie artikel word Gereformeerd (met' $n$ hoofletter) gebruik in verwysing na die teologie of hermeneutiek soos beoefen in die GKSA.

2.T.F. de Haan was ' $n$ kenner van die antieke tale (Hebreeus, Grieks en Aramees) en is ook met die oprigting van die Teologiese Skool Kampen (1854) tot eerste professor in Antieke Tale benoem. De Haan het Postma ingelei in die eerste beginsels van taalstudie en ' $n$ liefde vir die ou tale by Postma gekweek (Van der Vyver 1958:47).

3.Verskeie kere het Postma sy 'onvermogen' om as dosent op te tree, en die ontoereikendheid van sy wetenskaplike kennis bely. Hy het sy benoeming as dosent en later professor met groot huiwering aanvaar (Van der Vyver 1958:373, 379, 380). 
bevestiging as predikant in Nederland, het Postma aangebied om te help met die indiensopleiding van predikante vir die CAGK. Van die ses studente wat in Nederland deur hom opgelei is, is vier suksesvol deur die sinode geëksamineer en tot die bediening toegelaat. ${ }^{4}$

Met sy koms na Suid-Afrika het Postma dus reeds onderrigervaring gehad. Kort na die stigting van die Gereformeerde Kerke in Suid-Afrika (GKSA) het hy dan ook begin met die indiensopleiding van predikante, want die behoefte was groot. ${ }^{5}$ Aangesien Postma in hierdie dae meestal op reis was, was die ossewa saans die studievertrek vir sy leerlinge. Vanaf 1866, toe hy die beroep na Burgersdorp aanvaar het, het die opleiding in sy studeerkamer plaasgevind (Ras 1981:12, 14). Uiteindelik sou 20 bedienaars van die woord waaronder J. Lion Cachet, W.J. Snyman, M. Postma en P. Postma onder Postma se leiding hulle studie in Suid-Afrika voltooi. Dit was persone wat op hulle beurt weer as dosente en professore op die volgende geslag teologiese studente invloed sou uitoefen. Postma se teologie en hermeneutiek het op hierdie wyse van die begin af 'n bepalende en blywende invloed op die GKSA gehad.

Met die formalisering van die teologiese opleiding in die stigting van die Teologiese Skool Burgersdorp, is daar op Postma se aandrang grootliks gesteun op die voorbeeld van die Teologiese Skool te Kampen, wat in 1854 deur die CAGK in Nederland opgerig is. Postma self was destyds in Nederland intens hierby betrokke ${ }^{6}$ (Van der Vyver 1958:92103). Die leerplan vir die Teologiese Skool te Burgersdorp was volgens besluit van die Sinode van 1869 vasgestel as die aangewese wetenskappe wat deur die sinodale besluit van die CAGK (1851) goedgekeur is (Acta 1869:22). ${ }^{7}$ Hierdie leerplan het 'n geweldig omvangryke en ensiklopediese kennis van Postma (en later Cachet) as dosente verwag.

Dit laat die volgende vraag ontstaan: Watter studiemateriaal het Postma in sy teologiese opleiding gebruik? Postma self antwoord hierop wanneer hy in 1875 sy Mijne Handleiding voor de Godgeleerdheid publiseer. In die voorwoord sê Postma (1875:iii) dat hy sy gedagtes op skrif stel en nalaat 'opdat niemand naderhand behoeft te vragen: Wat heeft Postma onderwezen'.

4. Hulle was E.R. Breitsma, J. Beijer (wat later ook na Suid-Afrika sou kom), S. Sijpkens en W.H. van den Bosch (Van der Vyver 1958:59)

5.Die beroeping van predikante uit Nederland was, met uitsondering van ds Beyer in 1862, nie suksesvol nie, en om studente uit Suid-Afrika in Nederland te laat ople was op daardie stadium ' $n$ te duur en tydrowende onderneming.

6.Postma speel ' $n$ prominente rol in die aanloop tot die uiteindelike besluite van die Nasionale Sinodes van die CAGK in 1846 en 1849 oor die oprigting van 'n eie teologiese skool. Wanneer die finale besluit in 1854 geneem word, is hy die ondervoorsitter van die Sinode. Van die oprigting van die Teologiese Skool Kampen tot en met Postma se vertrek na Suid-Afrika (1858), dien hy as kurator en penningmeester. Die waarderingswoord wat die dosente en studente met sy vertrek aan hom rig, getuig van die besondere band wat hy met die skool gehad het (Van der Vyfer 1958:103; Vergeer \& Du Plooy 2008:16)

7.Volgens Jooste (1958:115) was die aangewese wetenskappe die volgende: Hollandse taal en styl, Latyn, Grieks, Hebreeus. Algemene Geskiedenis, Geografie, Mitologie, taal en styl, Latyn, Gieks, He, Redekunde, 'Boven Natuunde', Bybelse Geskiedenis, Bybelse Geografie, Joodse Oudhede, Kerklike Geskiedenis, die Gronde van Bybelse Uitlegkunde, Natuurlike Godgeleerdheid, Geopenbaarde Godgeleerdheid (stellig, weerleggend en beoefenend), Herderlike Werk, 'Predikkunde', Kategetiek, die Drie Formuliere van Eenheid, Liturgiese Geskrifte en Kerkregering.
In hierdie artikel word die impak van wat Postma 'onderwezen heeft' ondersoek - in besonder ten opsigte van die Gereformeerde Hermeneutiek. Die oorsprong en die inhoud van die beginsels wat hy uiteensit vir die verklaring van die Heilige Skrif, word nagevors en twee redelik onlangse publikasies wat riglyne vir die Gereformeerde Hermeneutiek uiteensit, word hieraan gemeet. Ten slotte word bepaalde definiërende kenmerke van die Gereformeerde Hermeneutiek omlyn, met die oog op die verdere uitbouing van die Gereformeerde Teologie in die toekoms.

\section{Wortels van die Gereformeerde Hermeneutiek: Aegidius Francken}

Dit blyk dat Postma in sy studiemateriaal en teologiese beskouings grootliks op die opleiding terugval wat hy self ontvang het. In hierdie verband het een bron 'n sentrale plek beklee, naamlik die Kern der Christelijke Leere deur Aegidius Francken (1713). Postma (1875:iii) noem dit dat hy en 'onze

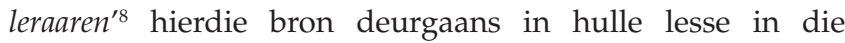
'Godgeleerdheid' gebruik het. Mettertyd het Postma, op versoek van sy studente, besluit om 'n handboek van sy eie lesse saam te stel en uit te gee 'tot hun gemak en dienst' (Postma 1875:iv). Hy noem dit Mijne handleiding voor de Godgeleerdheid volgens De kern van Aegidius Francken. Alhoewel hy grootliks Francken se indeling en inhoud volg, sê Postma (1875:iii) dat hy 'geheel vrij' te werk gegaan het. Van sekere dele van Francken se De kern (soos byvoorbeeld die 'weerleggende Godgeleerdheid') het hy egter 'niet veel werk gemaakt'.

Aegidius Francken was saam met bekende figure soos Voetius en A'Brakel 'n eksponent van die Nadere Reformasie - 'n beweging wat sedert die begin van die sewentiende eeu in Nederland ontstaan het en wat die beginsels van die Reformasie wou deurtrek na die alledaagse lewe (gesin, huis, skool, staat, politiek, samelewing en werkkring). Dit het gestreef na 'n balans tussen ortodoksie en piëteit. Later, toe die invloed van die Humanisme en Verligting in die kerke in Nederland begin deurwerk, het ondersteuners van die Nadere Reformasie in 1834 die Afscheiding bewerk waaruit ook die CAGK ontstaan het. Dit was die kerk waaraan Dirk Postma behoort het toe hy na Suid-Afrika gekom het.

Francken (1676-1743), self 'n pastoriekind, het aan die Leidse Universiteit studeer en het in 1705 predikant in die Nederduitsche Gereformeerde Kerk geword. ${ }^{10}$ Francken (1710) was die skrywer van verskeie teologiese werke waarvan die bekendste met die titel Stellige God-geleertheyd, dat is de Waerheden van den Hervormde Leer, eenvoudig ter nedergestelt, en met oefening der waere godsaligheyd aangedrongen 'n drieledige dogmatiese handleiding vir gemeentelede was.

8.Moontlik verwys Postma hiermee ook na die dosente aan die Teologiese skool te Kampen.

9. Hiervoor, sê Postma (1875:iii), gebruik hy eerder die tweede deel van P. Nahuys se Kort Begrip der Christelijke Religie (1866).

10. Hierdie kerkverband is in 1571 te Emden gestig en het in 1579 die amptelike staatskerk van die Republiek der Zeven Verenigde Nederlanden geword. Met die inval van die Franse in 1795 het dit opgehou om Staatskerk te wees. In 1816 het Koning Willem I die kerk van'n nuwe reglement voorsien en het die naam verander na Nederlandsche Hervormde Kerk. So het dit weer die amptelike staatskerk van Nederland geword. 
Later gee hy (Francken 1713) ook 'n verkorte weergawe uit, naamlik Kern der Christelyke leere, dat is de waerheden van den hervormde godsdienst, eenvoudig ter nedergestelt, en met oefening der waere godsaligheyd aangedrongen. Hierdie werk wat die basis vir Postma se Mijne Handleiding vorm, is deurlopend in die kringe van die Afscheiding as gesaghebbend beskou. Ook in ander wêrelddele waar die gereformeerde teologie hom in die negentiende eeu gevestig het, is hierdie bron in die opleiding van predikante gebruik. ${ }^{11}$

\section{Postma se Mijne Handleiding}

In sy Mijne Handleiding stel Postma in 33 hoofstukke die belangrikste leerstellings van die Gereformeerde Teologie aan die orde. Hy doen dit aan die hand van vrae en antwoorde soos in die Heidelbergse Kategismus, maar laat hom wat die indeling en inhoud betref (soos Francken) baie meer deur die Nederlandse Geloofsbelydenis (NGB) lei. In hoofstuk 2 behandel hy Het Woord Gods in 101 Vrae en Antwoorde. Dit is hoofsaaklik in hierdie deel waar die vertrekpunte en riglyne omskryf word, wat tot vandag toe die kern van die Gereformeerde Hermeneutiek uitmaak. Vervolgens word enkele aspekte soos Postma dit behandel, oorsigtelik uiteengesit, met 'n kursoriese aanduiding van die verdere ontplooiing daarvan in die Gereformeerde Hermeneutiek.

\section{Wetenskaplike voorvrae}

In die eerste hoofstuk van sy Mijne Handleiding hou Postma hom in 33 vrae en antwoorde besig met sake wat verband hou met die Kenteorie. Vanuit die vertrekpunt dat gemeenskap met God die hoogste goed is, beredeneer Postma (1875:1-2) dat 'n mens deur 'rechte kennis' hieraan deel kan kry. Hy (Postma 1875:2-3) onderskei in hierdie verband tussen natuurlike en bonatuurlike kennis van God. Eersgenoemde verdeel hy in 'ingeschapene' en 'verkregene' kennis van God. Die natuurlike mens kan kennis van God kry deur sy 'redelijkheid' (Postma 1875:9, V\&A 26). Hierdie natuurlike kennis sluit egter die volgende uit: kennis van die verborgenheid van die Drie-eenheid, Christus die Middelaar, die regte weg van die saligheid, die volmaakte reëls vir die geloof en lewenswandel, asook die grootheid van die mens se ellende. Al hierdie kennis is bonatuurlik en bereik ons langs die weg van openbaring (Postma 1875:10).

In hoofstuk 2 stel Postma, sonder om genuanseerd daarop uit te brei, ook die saak van die verhouding tussen geloof en rede op 'n ietwat dubbelsinnige wyse aan die orde. Enersyds moet 'n Skrifverklaarder sy eie wysheid 'mistrou' (Postma 1875:41, V\&A 94), omdat die menslike rede deur sonde verduister is (p. 43, V\&A 99) en die Bybel baie dinge bevat wat bo die menslike begrip uitgaan. Andersyds is die menslike rede ook onmisbaar en 'van groote dienst' vir die verstaan van die goddelike waarhede (Postma 1875:43, V\&A 99). Die ontknoping van hierdie spanning vind hy in die verligting en leiding deur die Heilige Gees. In alle gevalle

11. Francken se Kern der Christelijke Leere is byvoorbeeld ook gebruik aan die Calvin Theological Seminary wat in 1876 vir die opleiding van predikante in Michigan, VSA, opgerig is. Die direkte invloed en lyn van Francken na bekende teoloë soos Gerhardus Vos en Louis Berkhof word deur Jones (2015) beredeneer. moet die eksegeet die Goddelike openbaring glo, maar voeg Postma (1875:43, V\&A 99) daaraan toe, 'echter nimmer iets strijdigs tegen de gezonde rede'.

Die kenteoretiese debat en die vraag na vooronderstellings in die Gereformeerde Hermeneutiek, sou in die latere jare geweldig uitbrei in omvang en kompleksiteit. Veral sedert die sestigerjare van die vorige eeu, sou nuwe beskouings oor taal, die aanvaarding van 'n relatiewe waarheidsmodel deur sommige kerkverbande en die opkoms van die paradigmaleer stimulus hieraan verleen. Gereformeerde teoloë het hulle in verskeie artikels ${ }^{12}$ hieroor verantwoord, en veral teenoor die relativistiese waarheidsbeskouing bly vashou aan die geloofsvertrekpunt dat die Bybel God se woord is en dus die objektiewe en onfeilbare waarheid is. Terselfdertyd is daar bly worstel met die vraag hoe hierdie objektiewe waarheid vir die subjektiewe en deur-die-sonde-gebroke mens toeganklik is. ${ }^{13}$ In hierdie verband moes die Gereformeerde Hermeneutiek die middeweg tussen fundamentalistiese objektivisme aan die een kant, en relativistiese en liberalistiese subjektivisme aan die ander kant probeer vind.

\section{Die Bybel is God se woord}

Soos sedertdien in alle uiteensettings van die Gereformeerde Hermeneutiek tot op hede, neem Postma (1875:14-18, V\&A 1-15) sy vertrekpunt in die belydenis dat die Bybel die Woord van God is. In sy uiteensetting en beredenering hiervan volg hy grootliks die NGB.

Vir Postma (1875:33, V\&A 67) is slegs die Bybel in sy grondteks die Woord van God en dus gesagvol. Elke 'overzetting' [vertaling] beskou hy as mensewerk en feilbaar. In navolging hiervan is wetenskaplike kennis van grondtale van die Bybel deurlopend en tot vandag toe 'n belangrike basis vir die Gereformeerde teologiese opleiding en Skrifverklaring. In hierdie opsig is wonderlike bronne, tegnieke en tegnologiese hulpmiddels in die afgelope 150 jaar ontwikkel wat kennis van die Bybel in sy grondtale uitgebrei het, en selfs binne die bereik van gewone lesers gebring het (Van der Watt 2012). Gereformeerde teoloë het hiertoe bydraes van hoogstaande waarde gelewer. Dit sluit in bydraes op die gebied van tekskritiek, grammatika, die ontwikkeling van modelle vir die ontleding van sintaktiese en gedagtestruktuur asook woordeksegese. ${ }^{14}$

\section{Die inspirasie van die Bybel}

Postma (1875:18, V\&A 19) bely, soos in die NGB, Artikel 3 en 5, dat die Bybelskrywers onfeilbaar deur die Heilige Gees gelei is. Tog, sê hy (Postma 1875:27, V\&A 45) ook dat God op menslike wyse - in menslike taal - praat. Sonder om dit eksplisiet so te noem, handhaaf hy dus 'n organiese

12.'n Voorbeeld is die debat tussen Lion-Cachet $(1984 ; 1985)$ en Deist (1984), en die artikels van onder meer Coetzee (1979), Botha (1986), Snyman (1992a; 1992b) en Vergeer (1993)

13.Lees byvoorbeeld die artikels van Jordaan et al. (2011:232-234) en die publikasies onder redaksie van De Klerk en De Wet (2013).

14.Vergelyk byvoorbeeld die publikasies van Snyman (1956), Coetzee (1988; 1997), Jordaan (1991) en Janse van Rensburg (1986; 2011). 
inspirasieleer - 'n insig wat later in die Gereformeerde Hermeneutiek geformuleer is as 'God se woord deur mense' (Janse van Rensburg \& Kruger 2008:73; Jordaan, Janse van Rensburg \& Breed 2011:229).

Anders as wat Le Cornu (2010:2) beweer, ${ }^{15}$ het Postma wel ' $n$ oog gehad vir die historiese konteks van die Skrif. In 'n beredenering van die moontlikheid of die sin van die Skrif, soos die Heilige Gees dit bedoel, ook dubbelsinnig kan wees, erken hy byvoorbeeld dat die verstaan van die boodskap van 'n Skrifgedeelte in die konteks van die eerste ontvanger as historiese persoon tot ' $\mathrm{n}$ ander uitsig op die betekenis daarvan kan lei. Hy (Postma 1875) sê:

Wel erkennen wij dat eene geschiedenis, of ook een historisch persoon als eerste onderwerp voorkomt, en dan vervolgens tot een andere bedoelde word overgegaan, maar dit is daarom niet dubbelzinnig. (p. 38, V\&A 86)

Postma se beskouing oor die inspirasie bring mee dat die verklaring van die Skrif na sy mening nie sonder die leiding van die Heilige Gees kan plaasvind nie. Deurgaans in sy hermeneutiek lê hy daarom 'n sterk pneumatologiese aksent. Die verklaarder het die Heilige Gees nodig om die Skrif 'recht en tot zijne zaligheid' te verstaan (Postma 1875:29, V\&A 51). Die werk van die Gees in hierdie verband bestaan uit 'innerlike verlichting en onderwijzing' wat die verduisterde verstand moet opklaar (Postma 1875). Verder is die Heilige Gees ook nodig om die wil van die leser te buig tot 'n gelowige erkenning van die Goddelike waarheid en om die inwendige sekerheid daaroor te bewerk (Postma 1875:20, V\&A 25). Hierdie insigte sou deur Du Toit (Totius) uitgebou word tot die erkenning van die kongenialiteitsnoodsaak tussen die eksegeet en die Heilige Gees (Venter 1977:63-67). Coetzee, De Klerk en Floor (1980) beredeneer later in 'n invloedryke artikel die noodsaaklikheid hiervan in die bybelse beoordeling van kerklik-etiese vraagstukke.

\section{Die gesag van die Bybel}

Postma (1875:26, V\&A 41) bely en leer dat die gesag van die Skrif nie van mense of die kerk afhang nie, maar in die Skrif self lê. Soos in die NGB, Artikel 5, bely hy (Postma 1875:97) egter dat hierdie gesag in die eerste plek vir die geloof geld: 'De Bijbel onderwijst ons dus niet natuurkunde, maar geloof en godzaligheid'.

Tog gaan hy (Postma 1875:95-100, V\&A 28) daarna voort om op 'n (vir sy dae) baie progressiewe manier die bybelse uitsprake dat die son op en onder gaan, vanuit'n Kopernikaanse wêreldbeeld te verduidelik. Hy (Postma 1875:99) weerlê ook die idee dat die aarde letterlik op vier pilare staan en verduidelik dat die aarde draai en nie stilstaan nie. Verder stel hy (Postma 1875:93-94, V\&A 17-19) met beslistheid dat die Skepping in ses dae (tydperke van 24 uur) plaasgevind het. Hierdie strewe om ook die natuur in die lig van die Skrif te 15.Le Cornu (2010:2) sê: "Postma glo dat die sin van die Skrif is "wat de H. Geest daarin
bedoelt" (en dus nie wat die sosio-historiese konteks bepaal of "eerste hoorders" bedoelt" (en dus nie
verstaan het nie).' bestudeer, sou in die volgende 150 jaar vanuit die Teologiese Skool tot 'n volwaardige universiteit ontwikkel.

\section{Die eienskappe van die Bybel}

Op uitgebreide wyse bespreek Postma (1875:20-33, V\&A 22-65) in Mijne Handleiding vyf eienskappe van die Skrif: die Goddelikheid (pp. 20-27, V\&A 23-42), Waarheid (pp. 27-28, V\&A 43-45), 'Klaarheid' [Duidelikheid] (pp. 28-29, V\&A 46-51), Volmaaktheid (pp. 29-32, V\&A 52-60) en Noodsaaklikheid (pp. 32-33, V\&A 61-65) van die Skrif word aan die orde gestel. Elders in Mijne Handleiding behandel Postma (1875:25, V\&A 37) ook die Eenheid en die Geloofwaardigheid (p. 20, V\&A 27) van die Skrif. Hierdie Skrifbeskoulike vertrekpunte kom van die Reformasie en word tot vandag toe in die Gereformeerde Hermeneutiek gehandhaaf (Coetzee et al. 1980; Jordaan 1991).

\section{Die verstaan van die Bybel}

Dit is volgens Postma (1875:39-40, V\&A 88, 93), die roeping en plig van gewone lidmate en predikante (p. 42, V\&A 95) om die hele Skrif (Ou en Nuwe Testament) te lees en te verklaar. Die gedagte dat die Skrifverklaring ook op die vlak van gewone lidmate tuishoort, is 'n sterk Gereformeerde tradisie. ${ }^{16}$

Die sin van Skrifverklaring is volgens Postma (1875:38, V\&A 86), om te bepaal wat die Heilige Gees bedoel. Dit is daarom duidelik dat Skrifverklaring vir Postma nooit net 'n akademiese oefening is nie, maar 'n geloofsdaad waarin die Heilige Gees persoonlik met die Skrifverklaarder bemoeienis maak. Die Gereformeerde hermeneut benader die Skrif met 'n godvresende gemoed en 'n biddende hart, en 'moet hij zijne eigen wijsheid mistrouwen' (Postma 1875:41, V\&A 94). Die hele hermeneutiese proses moet ook begelei word deur gelowige nadenke, inkeer en stigtelike gesprekke met medegelowiges (Postma 1875:44, V\&A 102).

Tog bly die wetenskaplike ondersoek van die Skrif nie hierin agterweë nie. Om die bedoeling van die Heilige Gees (as 'zin' van die Skrif) te bepaal, moet die verklaarder, volgens Postma (1875:41, V\&A 94), 'hoogst nodig aandachtig' op vyf sake let. Dit is (1) die oogmerke van die skrywer; (2) die samehang van die rede; (3) die krag van woorde en uitdrukkings; (4) gelykluidende plekke; en (5) die ooreenkoms van die geloof (belydenis). In die vyf sake wat hy noem, vestig Postma 'n basis vir die Gereformeerde eksegese wat, ten spyte van geweldige uitbreiding en spesialisering in die jare wat sou volg, steeds daaraan ten grondslag lê. Postma se 'vyf sake' kan byvoorbeeld duidelik in twee onlangse uiteensettings van die Gereformeerde hermeneutiek ${ }^{17}$ teruggevind word:

16.Daar was byvoorbeeld al in 1927 sterk aandrang vanuit Gereformeerde hoek dat die Afrikaanse Bybel (net soos die Statevertaling) ook van kanttekeninge voorsien moet word sodat gewone lidmate die Skif kan uitlê en toepas (Du Toit 1959b: 164-169).

17.As steekproef in die verband is die boek Preekgeboorte: Van eksegese tot preek (Janse van Rensburg 2011) en die artikel Hermeneutiese vertrekpunte vir gereformeerde eksegese (Jordaan et al. 2011) gebruik. Eersgenoemde dien as handleiding vir teologiese studente, terwyl laasgenoemde in verskeie onlangse handleiding vir teologiese studente, terwyl laasgenoemde in verskeie onlangse
teologiese proefskrifte en verhandelings vanuit Gereformeerde hoek aangedui word as die uiteensetting van die hermeneutiek wat in die studie gevolg word. 
- In die aandag wat Postma vra vir die 'oogmerke van die skrywer', lê die hedendaagse ondersoek na die konteks van die skrywer en hoorders, die genre van die teks, ${ }^{18}$ die sosio-historiese en kultuur-historiese gerigtheid van die teks, asook die onderskeiding tussen die indikatief en imperatief van die teks (Janse van Rensburg 2011:139158; Jordaan et al. 2011:245, 247).

- In die vraag na die 'samehang van die rede' lê in wese die besef dat grammatiese, sintaktiese en gedagtestruktuurontleding noodsaaklik is om die fokuspunt in die teks te identifiseer en dit van die bysaak te onderskei (Janse van Rensburg 2011:33-138; Jordaan et al. 2011:247).

- Die ondersoek na die 'krag van woorde en uitdrukkings' dui op die noodsaak van woordeksegese en semantiese en morfologiese analise. Hedendaagse insigte in die retoriek en narratologie lewer ook 'n bydrae tot die verstaan van die krag van woorde en uitdrukkings (Janse van Rensburg 2011:159-202; Jordaan et al. 2011:235).

- Postma se fokus op 'gelykluidende plekke' word vandag 'Skrif met Skrif vergelyking' en 'die bepaling van die openbaringshistoriese plek van die perikoop' genoem. Hedendaagse insigte in die verhouding tussen die Ou en Nuwe Testament lewer ook hiertoe 'n bydrae (Janse van Rensburg 2011:203-218; Jordaan et al. 2011:248-250).

- Die soeke na 'ooreenkoms van die geloof' dui op die belangrikheid van die eksegetiese bevindingskontrolering van die belydenis en van eksegetiese en homiletiese bronne (Janse van Rensburg 2011:233-244, 258-288; Jordaan et al. 2011:233).

\section{Die hantering van verskille in Skrifverklaring}

Ten slotte stel Postma (1875:43-44, V\&A 100), in sy hoofstuk oor Het Woord Gods, 'n tema aan die orde wat in baie moderne hermeneutieke ontbreek en wat vandag uiters relevant is, naamlik wie dan onfeilbaar oor die betekenis van die Skrif kan beslis wanneer daar 'n verskil van mening bestaan.

Postma verset hom baie ernstig teen die gedagte dat 'n bepaalde persoon as regter kan dien om in verskille oor die betekenis van die Skrif te beslis. Enige persoon (soos byvoorbeeld die Pous) het, omdat die menslike rede verduister is (Postma 1875:43, V\&A 98), self ook maar net 'n (feilbare) menslike mening (Postma 1875:42, V\&A 97).

Alhoewel Postma (1875) die toekenning van die beslissingsreg in verskille aan ' $n$ kerklike vergaderings as beter beskou, wys hy ook dit van die hand. Met bewyse uit die Skrif beredeneer hy hoe van die vernaamste kerklike vergaderings soms teen God se wil en wet, ' ja, tegen alle recht en rede', gehandel het. Volgens hom (Postma 1875:43, V\&A 97), bewys ook die geskiedenis dat, ten spyte van 'algemeene stemmen', kerklike vergaderings

18.Postma (875:41, V\&A 41) self maan byvoorbeeld reeds tot sensitiwiteit vir die feit dat' $n$ bepaalde Skrifgedeelte' $n$ figuurlike betekenis kan hê, 'hetwelk evenwel in de $H$. Schrift dikwerf het geval is', en wys daarop dat verskillende literatuursoorte $H$. Schrift dikwerf het geval is', en wys daarop dat verskillende literatuursoorte
verskillend verklaar moet word, veral waar die 'spreekwijzen der $H$. Schrift verskillend verklaar moet word, veral waar die 'spreek
dichterlijk en zinnebeeldig' is (Postma 1875:99, V\&A 28). dikwels gefouteer het en dus die finale beslissingsreg in geskille oor die betekenis van die Skrif 'onwaardig' is. ${ }^{19}$

Volgens Postma (1875:43-44, V\&A 100) is dit alleen die Heilige Gees wat in die Woord spreek wat onfeilbaar oor die betekenis van die Skrif kan beslis. Daarom moet die verskillende standpunte duidelike gronde in die Heilige Skrif hê, en die Skrif moet met Skrif vergelyk word. Die Gees spreek ook in die gewete van die gelowige.

\section{Die impak van teologie op die Gereformeerde Hermeneutiek}

Soos aangetoon, was Dirk Postma se hermeneutiese vertrekpunte en riglyne geensins 'n nuutskepping nie. Dit was 'n direkte weergawe van die standpunte van Aegidius Franken en die Nadere Reformasie. Die Nadere Reformasie het op sy beurt die eksegetiese praktyke van die Reformatore en die vroeë Christelike kerk nagevolg. Dit is hierdie praktyke wat aan die wortel van die grammaties-historiese model van eksegese lê, wat vandag in die GKSA nagevolg word (Jordaan et al. 2011:234; Van Deventer 2009).

Die impak van Dirk Postma se hermeneutiek op die teologie van die GKSA kan moeilik onderskat word. Hy was self die enigste dosent van Jan Lion Cachet wat hom as professor opgevolg het. Cachet was op sy beurt weer die dosent van J.D. du Toit (Totius) wat as eerste wetenskaplike uitbouer van die Gereformeerde Hermeneutiek beskou kan word. Waar Postma en Cachet, volgens Stephanus du Toit (1959a:49), 'nog enigsins gemoedelik' in hulle teologie was, het die Gereformeerd-wetenskaplike ontplooiing van die hermeneutiek by Du Toit begin, ${ }^{20}$ en het hy (Du Toit 1959a:56) 'die grondslae van 'n deeglike eksegetiese metode gelê'. 'n Hele geslag studente, waaronder verskeie toekomstige teologiese professore, ${ }^{21}$ het hulle vorming as eksegete en hermeneute by $\mathrm{Du}$ Toit ondergaan, en op hierdie manier is ' $n$ hermeneutiese tradisie gevestig waarvan die lyne deurloop tot vandag toe. Daar kan met reg beweer word dat die Gereformeerde Hermeneutiek vandag in wese steeds begrond is in die beginsels wat Postma in Mijne Handleiding uiteengesit het en dat dit ' $n$ beslissende impak op die Gereformeerde teologie gehad het en steeds het.

Om hierdie impak te probeer verwoord, kan daar ten slotte enkele definiërende kenmerke aangedui word. Die Gereformeerde teologie gaan uit van die volgende:

19.In hierdie opsig kan met reg gevra word of die GKSA in sy hantering van die vraagstuk oor die toelating van vroue tot die besondere dienste nie van hierdie historiese hermeneutiese vertrekpunt afgewyk het nie. Die verskil van mening oo die betekenis van die Skrif in hierdie verband is sedert 2009 deur kerklike vergaderings met meerderheidstem op die spits gedryf.

20.Du Toit (1928:57) self het vroeg in sy bediening as professor opgemerk dat die wetenskaplike ontplooiing van die hermeneutiek 'van ons kant verwaarloos is'. Hy het in verskeie van sy publikasies van hierdie agterstand werk gemaak (vgl. Du Toit 1930; 1941). Die besondere bydrae wat Du Toit hierin tot die hermeneutiek gelewer het, is 'n (tot nog toe) onontginde studieterrein.

21. Hieronder is S. du Toit (Ou Testament), W.J. Snyman (Nuwe Testament), J.P. Jooste (Kerkreg en Kerkgeskiedenis), P.J.S. de Klerk (Dogmatologiese vakke) en B.J. de Klerk (Apologetiek en Etiek). 


\section{'n Hermeneutiek wat 'n geloofsdaad is}

Gereformeerde Skrifverklaring het hom deurlopend en in die eerste plek altyd opgestel as 'n gelowige antwoord op die woord van God. Postma (1875:39-42) het die uitleg van die Skrif as 'n roeping teenoor God beskou - 'n roeping waarin die weergeboorte en verligtende leiding van die Heilige Gees onontbeerlik is (p. 29). In hierdie verband bly Du Toit se uitspraak dat die Gereformeerde Hermeneutiek 'n heilige land is wat sonder skoene betree moet word, 'n treffende formulering (Venter 1977:65).

'n Gelowige en vroom lewe in oorgawe aan God is dus deurgaans die hoogste voorwaarde vir die Gereformeerde hermeneut. Die Gereformeerde Hermeneutiek is nie in die eerste plek 'n leer of Skrifbeskouing nie; dit is Skrifgeloof en godsdiens wat uit 'n kinderlike onderwerping bestaan, juis omdat dit God se woord is (Van der Walt \& Du Toit 1959:301). Dit is genade dat God in die afgelope 150 jaar aan die GKSA in sy professore sulke uitnemende voorbeelde in hierdie opsig geskenk het. Waar die wetenskaplike bekwaamheid van voorgangers (volgens hulle eie erkenning) enigsins ontbreek het, was hulle toewyding aan God en sy diens onbesproke.

Ook vandag nog geld die waarheid dat die Skrif en die koninkryk van God net waaragtig verstaan kan word deur hulle wat godsdienstig daarin wil lewe. Die aktiewe en gedissiplineerde beoefening van gelowige meditatio [oorpeinsing], tentatio [beproewing] en precatio [gebed] ${ }^{22}$ behoort dus in die Gereformeerde Hermeneutiek nie net aangemoedig te word nie, maar inderdaad ook ondersoek en onderrig te word as 'n wesenlike deel van die Gereformeerde eksegetiese proses.

\section{'n Hermeneutiek wat streef na wetenskaplik- verantwoordbare uitnemendheid}

Cachet (1911:6) se droom van 'n teologiese skool wat 'n tempel vir die wetenskap sou wees, met God se woord as hoeksteen, kan as 'n deurlopende tema in die ontwikkeling van die Gereformeerde teologie en hermeneutiek beskou word. Postma self het gesê: 'hoe beter studente literaries ontwikkel is, hoe beter teologiese studente sal hulle wees' (Van der Vyver 1958:380). Die uitbreiding van die onderrig aan die teologiese skool te Burgersdorp om ook ander vakke in te sluit, en die skeiding van die literariese eksamen van die teologiese eksamen in 1876, was daarop gemik om studente te lewer wat akademies meer gevorderd was. Die toelatingsvereistes (admissie-eksamen) vir teologiese studie is ook gaandeweg verhoog (Van der Vyver 1958:380).

Hierdie strewe na wetenskaplike uitmuntendheid staan in die Gereformeerde teologie nie teenoor die beoefening van die hermeneutiek as geloofsdaad nie, maar is juis deel van die uitlewing daarvan. In die gelowige Skrifverklaring streef Gereformeerde teoloë na resultate waaroor hulle hul teenoor God en die wêreld redelik (rasioneel) kan verantwoord. In 22.Soos voorgestel deur Du Toit (Venter 1977:69). die afgelope 150 jaar het hierdie strewe inderdaad gegroei tot 'n hele universiteit van verbasende omvang. In hierdie universiteit lewer Gereformeerde teoloë steeds (kwantitatief en kwalitatief) wetenskaplike uitsette van die hoogste standaard.

Die potestas doctrinae [vermoë om te leer] as geskenk van God roep die Gereformeerde teoloog voortdurend op tot verdere studie, besinning en verbetering. In hierdie verband is dit uit die geskiedenis duidelik dat die blootstelling aan en samewerking met gereformeerde teoloë wêreldwyd ${ }^{23}$ die verdere ontwikkeling van die Gereformeerde hermeneutiek bevorder het. Die huidige tegnologies gevorderde leefwêreld en vryvloei van inligting bied in hierdie opsig besondere moontlikhede.

\section{'n Hermeneutiek wat hom apologeties opstel}

Die Gereformeerde Hermeneutiek is in sy wese (soos die belydenisskrifte) ook apologeties. Dit wil enersyds uiteensit hoe die Skrif gelowig en geldig verklaar kan word, maar andersyds ook hoe dit nie verklaar moet word nie. Afwykende beskouings oor die Skrif en Skrifverklaring noodsaak die Gereformeerde Hermeneutiek om steeds duideliker, meer uitgebreid en spesifiek te wees.

So byvoorbeeld lê die wortels van die Gereformeerde Hermeneutiek in die Reformasie. Die Reformasie het uit verset teen die Roomse hermeneutiek teruggekeer het na die waarde van die Skrif as woord van God en die grammatieshistoriese uitleg daarvan (ad fontes). Nader bepaal lê die wortels van die Gereformeerde Hermeneutiek ook in die hermeneutiek van die CAGK. Die CAGK het ontstaan as reaksie teen die liberalistiese gety van die negentiende eeu in Europa, met sy verligte en optimistiese antropologie waarin godsdiens bloot as 'n ontplooiing van die bewussyn van die redelik-sedelike mens beskou is (Schutte 2009:3, 6).

Soortgelyke uitdagings staan die GKSA in die huidige tydsgewrig voor die boeg. Dit bly daarom belangrik dat Gereformeerde teoloë en teologiese studente belese moet wees en dat hulle toegerus moet word om met fyn onderskeiding 'n wye verskeidenheid van filosofiese en hermeneutiese oortuigings en standpunte krities te evalueer.

\section{'n Hermeneutiek wat gebonde aan die belydenis vry wil wees}

Du Toit (1928:59) se uitspraak dat die Skrifverklaarder as gelowige 'hom gebind sal weet deur die Christelike belydenis', maar 'as man van die wetenskap vry moet bly', verwoord 'n strewe na onafhanklikheid wat as kenmerk van die Gereformeerde Hermeneutiek beskou kan word. Vir die Gereformeerde Hermeneutiek om in sy gebondenheid aan die belydenis onafhanklik en 'vry' te wees, is dit noodsaaklik dat ook die strukture waarbinne hy funksioneer, onafhanklik en vry sal wees.

23.Soos die geval met J.D. du Toit, T. van der Walt en andere wat in die buiteland studeer het. 
Reeds toe hy nog in Nederland was, het Postma hierdie waarheid ingesien en hom beywer vir 'n eie teologiese skool vir die CAGK, wat selfstandig en sonder staatsinmenging kon funksioneer ten spyte daarvan dat geldelike steun deur die staat hiermee prysgegee moes word (Van der Vyver 1958:147). Na verskeie mislukte pogings is daar te midde van groot tekorte, tog daarin geslaag om so 'n onafhanklike opleidingsinrigting op die been te bring (te Kampen in 1854). In navolging hiervan, het die oprigting van 'n eie selfstandige teologiese skool in 1869 te Burgersdorp vir die GKSA gevolg. Ook hier is groot offers van gewone lidmate gevra - lidmate wat in baie moeilike sosio-politiese en ekonomiese omstandighede verkeer het (Postma 1909:105-124).

Die verdere stryd om die behoud van die onafhanklikheid van 'n eie Christelike universiteit wat uit die oprigting van die teologiese skool ontstaan het, is ' $n$ dramatiese (en in baie opsigte tragiese) geskiedenis, ${ }^{24}$ waarvan die realiteite ons vandag konfronteer en wat dringende besinning vra. Ideaal gesproke, sal die vrye beoefening van 'n Gereformeerde hermeneutiek (en teologie) slegs tot sy reg kan kom aan 'n onafhanklike instelling waar die vakinhoud, personeel, navorsingsfokus en uitsette selfstandig, volgens eie Gereformeerde oortuiging en sonder beïnvloeding bepaal word.

\section{'n Hermeneutiek wat kontekstueel relevant is}

In sy strewe na onafhanklikheid het die Gereformeerde Hermeneutiek egter steeds diensbaar en relevant gebly in sy wetenskaplik-teologiese en sosio-politiese konteks. In die oprigtingsjare was dit veral die regverdiging van sy bestaan teenoor kritiek en die noodsaak aan die toerusting van sy leiers waarop gefokus is. Ook het landsomstandighede (oorloë en resessie) in die vroeë jare 'n rol gespeel in die hermeneutiese fokus van die Gereformeerde eksegese.

In die latere jare is die fokus, naas sosiale, politieke en kerkliketiese vraagstukke, ook deur filosofiese en epistomologiese stromings bepaal. Die bekende uiteensetting van Lategan (1984:1-14) wat verduidelik hoe die aksente in die historiese ontwikkeling van die hermeneutiek wêreldwyd van die bron (skrywer) na die teks (die Skrif) en daarna na die leser verskuif het, het ook 'n invloed op die fokus van die Gereformeerde Hermeneutiek uitgeoefen. ${ }^{25}$

Dit is ook vir die toekoms belangrik dat die Gereformeerde Hermeneutiek in sy konteks relevant sal bly. In die huidige tydsgewrig staan Suid-Afrika voor besondere uitdagings, en 24.Vergelyk die beskrywing van Van der Vyver (2006) en Van Eeden (2006).

25.Sedert die twintigerjare van die vorige eeu moes die Gereformeerde Hermeneutiek (onder leiding van Du Toit) hom oor die bronne-hipotese en die historiese kritiek verantwoord (Venter 1977:45-53). Vanaf die sestigerjare van die vorige eeu het die bestudering van die teks van die Bybel in die Gereformeerde Hermeneutiek besondere aandag ontvang en is metodes ontwerp om die grammatika, die sintaktiese struktuur en gedagtestruktuur van die teks te ontleed (Coetzee 1988; sintaktiese struktuur en gedagtestruktuur van die teks te ontleed (Coetzee 1988; Janse van Rensburg 1986). Sedert die tagtigerjare van die vorige eeu domineer die vrae en sosiale omstandighede van die leser en sy paradigma weer die fokus van die hermeneutiek. Besinning oor sosiale geregtigheid, menseregte, die rol van die vrou in kerk en samelewing en seksuele oriëntasie is voorbeelde hiervan. Hierme saam kom vrae oor die betekenis van die Skrif en hoe dit vanuit lesersperspektie ontgin word, opnuut in fokus (vgl. byvoorbeeld Coetzee et al. 1980; De Klerk \& De Wet 2013:53-72; Jordaan et al. 2011:226-234; Vergeer 1993:563-582; Vorster 2004). die lidmate van die GKSA beleef vervreemding in 'n humanistiese en sekulêre leefwêreld wat sienderoë ontaard. Dit is in hierdie omstandighede steeds nodig om ' $n$ duidelike en Gereformeerd-bybelse getuienis te laat hoor, en om lidmate te begelei om hoopvol en met roepingsbesef te lewe.

\section{'n Hermeneutiek wat daarna strewe om balans te vind}

Dit is opmerklik dat daar in die Gereformeerde Hermeneutiek (as reaksieverskynsel) van die begin af na equilibrium gesoek was. Daar was 'n strewe om te reageer, maar ook 'n waaksaamheid om te oorreageer.

Hierdie tendens strek terug tot by Aegidius Francken wat, alhoewel hy deel van die Nadere Reformasie was, tog nie met die Afscheiding meegegaan het nie. Die Nadere Reformasie self was 'n strewe na balans tussen ortodoksie en piëteit (Van Lieburg 2014:43-66). Postma, op sy beurt, was wel deel van die Afscheiding, maar hy het hom nie tuis gevoel by die ultraortodokse Kruiskerk of in Schortinghuys se vyf 'niete' nie ('ik wil niet, ik kan niet, ik weet niet, ik heb niet, ik deugd niet'). In sy teologie het Postma rasionalisme sowel as subjektivistiese skolastiek afgewys (Schutte 2009:6) ${ }^{26}$.

Alhoewel Postma, vanuit ons tyd beskou, as streng en konserwatief in sy beskouings voorkom, is hy, in die tyd toe hy nog in Nederland was, van ortodokse kant beskuldig dat hy in sy prediking ' $n$ 'veel te ruime aanbod van genade' doen en dat daar by hom te min nadruk op die menslike onmag en die uitverkiesing is. Schutte (2009:6-11) oordeel dat hy ook in sy latere prediking die genadeverbond sentraal gestel het, asook die oproep tot geloof bo lydelikheid en wêreldmyding. Postma was duidelik ook gematig in sy beskouings, byvoorbeeld oor die sing van die Evangeliese Gesange en die 'kerklike kleed' ${ }^{27}$

Ook Du Toit se teologie word gekenmerk deur 'n strewe om uiterstes te vermy. Opmerklik is byvoorbeeld sy (Du Toit 1928:63-67) versigtige formulering in verband met die beskrywing van die kongenialiteit tussen die eksegeet en die Heilige Gees, en in sy besinning oor die vryheid en die gebondenheid van die Gereformeerde Hermeneutiek (pp. 57-60).

Die stryd om balans te vind, kan ook teruggevind word in verskeie besprekings en besluite van die Nasionale Sinodes van die GKSA. Besprekings oor die gebruik van bekers of kelkies tydens die Nagmaal, oor die omdigtings van die Psalms en die toelating van vroue tot die besondere dienste het telkens twee standpunte aan die lig gebring. Dit het daartoe gelei dat die GKSA al as 'kerk van twee strominge' getipeer is. Tog moet oorweeg word of hierin nie eerder ' $n$ bepaalde dialektiese kenmerk van die Gereformeerde teologie en hermeneutiek na vore kom wat van meet af en wesenlik daartoe behoort nie.

26. Hierdie posisie het Postma lewenslank gehandhaaf. Hy keur byvoorbeeld een van sy eie studente uit Nederland (J. Beier) af op grond van sy 'subjektivistiese bevindelikheid' (Schutte 2009:11).

27.Die Evangeliese Gesange kon, volgens hom, met algemene instemming gesing word, maar moes in die geval van beswaar nie afgedwing word nie (Vergeer \& Du Plooy 2008:112-113). Die kerklike kleed het hy met verloop van tyd as menslike gewoonte 'afgedaan' (Vergeer \& Du Plooy 2008:130). 


\section{Slot}

Alhoewel oorsigtelik aangetoon, dui bogenoemde inligting daarop dat die Gereformeerde Hermeneutiek vanuit 'n vaste teologiese basis ontstaan en ook die afgelope 150 jaar ontwikkel het. Hierdie basis lê via Dirk Postma en Aegidius Francken in die beginsels van die Reformasie en Nadere Reformasie. Die uitdaging virdieGereformeerdeHermeneutiek vandag is om hierdie beginsels ook in die huidige tydsgewrig en omstandighede te handhaaf en verder te ontplooi. Mag elke Gereformeerde teoloog ook hierin 'n leerling word in die koninkryk van die hemel, om soos die voorgeslagte gedoen het, ou en nuwe dinge uit die Skrif na vore te bring (Matt 13:52).

\section{Erkennings \\ Mededingende belange}

Die outeur verklaar dat daar geen finansiële of persoonlike verbintenis is met enige party wat hom nadelig kon beïnvloed het in die skryf van hierdie artikel nie.

\section{Outeursbydrae}

W.C.V. was die enigste outeur betrokke by die skryf van die artikel.

\section{Etiese oorwegings}

Hierdie artikel volg alle etiese standaarde vir navorsing.

\section{Befondsingsinligting}

Hierdie navorsing het geen spesifieke toekenning ontvang van enige befondsingsagentskap in die openbare, kommersiële of nie-winsgewende sektore.

\section{Data beskikbaarheidsverklaring}

Die deel van data is nie van toepassing op hierdie artikel nie, aangesien geen nuwe data in hierdie studie geskep of ontleed is nie.

\section{Vrywaring}

Die sienings en menings wat in hierdie artikel uitgedruk word, is dié van die outeur en weerspieël nie noodwendig die amptelike beleid of posisie van enige geaffilieerde agentskap van die outeur nie.

\section{Literatuurverwysings}

Acta, 1869, Handelingen van de algemeene synodale vergadering van die Gereformeerde gemeenten van Zuid-Afrika vergaderd te Reddersburg, 17-18de Mei.

Botha, J., 1986, 'Die Gereformeerde Skrifbeskouing en moderne metodes van verklaring van die Nuwe Testament', Koers 51(3), 259-286. https://doi. org/10.4102/koers.v51i3.934

Coetzee, J.C., 1979, "n Ou boek in 'n nuwe wêreld, of 'n nuwe boek in 'n ou wêreld?', In die Skriflig 13(49), 4-15. https://doi.org/10.4102/ids.v13i49.781

Coetzee, J.C., 1988, 'Gedagtestruktuurontleding en die eksegese van die Heilige Skrifte', in J.C. Coetzee (red.), Koninkryk, Gees en Woord, pp. 19-37, NG Kerkboekhandel, Pretoria.
Coetzee, J.C., 1997, Hermeneutics and exegesis of the New Testament, EFJS Printers, Potchefstroom

Coetzee, J.C., De Klerk, B.J. \& Floor, L., 1980, 'Die hermeneuse van die Skrif met die oog op hedendaagse kerklik-etiese vraagstukke', Koers 45(10), 18-36. https://doi. org/10.4102/koers.v45i1.1135

De Klerk, B.J. \& De Wet, F.J. (reds.), 2013, Met die oog op God: Voorveronderstellings van die reformatoriese invalshoek op die praktiese teologie, Potchefstroomse Teologiese Publikasies, Potchefstroom.

Deist, F.E., 1984, "n Kritiese evaluering van die kritiek van F.N. Lion-Cachet', In die Skriflig 18(72), 47-56. https://doi.org/10.4102/ids.v18i72.1234

Du Toit, J.D., 1928, 'Die subjek van die uitlegging van die Ou Testament', in H. Venter (red.), Totius: Versamelde Werke, Band 1, pp. 56-69, Tafelberg Uitgewers, Kaapstad.

Du Toit, J.D., 1930, 'Wat is skrifkritiek?', in H. Venter (red.), Totius: Versamelde werke, Band 1, pp. 41-56, Tafelberg Uitgewers, Kaapstad.

Du Toit, J.D., 1941, 'Die Bybel is die Woord van God', in H. Venter (red.), Totius: Versamelde werke, Band 1, pp. 3-26, Tafelberg Uitgewers, Kaapstad.

Du Toit, S., 1959a, 'Jacob Daniël du Toit', in S. du Toit, K.S. van Wyk de Vries, W.J. Snyman, H.J.J. Bingle \& D.W. Krüger (reds.), Die Gereformeerde Kerk in Suid-Afrika 1859-1959: Gedenkboek by geleentheid van die eeufees, pp. 45-59, Dagbreekpers, Johannesburg.

Du Toit, S., 1959b, 'Die Gereformeerde Kerk en die vertaling van die Bybel, die beryming van die kerklied en kantaantekeninge', in S. du Toit, K.S. van Wyk de Vries, W.J. Snyman, H.J.J. Bingle \& D.W. Krüger (reds.), Die Gereformeerde Kerk in Suid-Afrika 1859-1959: Gedenkboek by geleentheid van die eeufees, pp. 164-169, Daid-Afrika 1859-1959: Gedenkbc

Francken, A., 1710, Stellige God-geleertheyd, dat is de waerheden van den Hervormde leer, eenvoudig ter nedergestelt, en met oefening der waere godsaligheyd aangedrongen, Johannes Braam, Dordtrecht.

Francken, A., 1713, Kern der christelyke leere, dat is de waerheden van den hervormde godsdienst, eenvoudig ter nedergestelt, en met oefening der waere godsaligheyd aangedrongen, Johannes Braam, Dordtrecht.

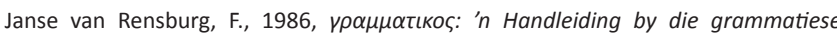
eksegese van die Griekse Nuwe Testament, PU vir CHO, Potchefstroom.

Janse van Rensburg, F. (red.), 2011, Preekgeboorte: Van eksegese tot preek, V\&R Drukkers, Pretoria.

Janse van Rensburg, F. \& Kruger, F., 2008, Leer die Bybel self verklaar, Christelike Uitgewersmaatskappy, Vereeniging.

Jones, M., 2015, Plagiarism? Berkhof copying Vos, viewed 5 August 2019, from https// www.reformation21.org/blog/2015/12/plagiarism-berkhof-copying-vos.php.

Jooste, J.P., 1958, Die geskiedenis van die Gereformeerde Kerk in Suid-Afrika 18591959, Potchefstroom Herald, Potchefstroom.

Jordaan, G.J.C., 1991, Skrifbeskouing: Deurslaggewende faktor by Skrifverklaring, Reeks H, Departement Sentrale Publikasies, PU vir CHO, Potchefstroom.

Jordaan, G.J.C., Janse van Rensburg, F.J. \& Breed, D.G., 2011, 'Hermeneutiese vertrekpunte vir gereformeerde eksegese', In die Skriflig 45(2-3), 225-258. https://doi.org/10.4102/ids.v45i2/3.14

Lategan, B.C., 1984, 'Current issues in the hermeneutical debate', Neotestamentica $18,1-14$.

Le Cornu, S., 2010, 'n Paar teologiese opvattings van Dirk Postma (1818-1990 [sic]), viewed 5 August 2019, from https://proregno.files.wordpress.com/2010/07/ teologiese-opvattings-van-dirk-postma2.pdf.

Lion Cachet, J., 1911, 'Wie veracht den dag der kleine dingen?': Afscheidswoord, A.H. Koomans, Potchefstroom.

Lion Cachet, F.N., 1984, "n Kritiese beskouing van Deist se "ABC van Bybeluitleg"', In die Skriflig 18(69), 38-51. https://doi.org/10.4102/ids.v18i69.1215

Lion Cachet, F.N., 1985, "n Antwoord op Deist se kritiek', In die Skriflig 19(75), 45-48. https://doi.org/10.4102/ids.v19i75.1258

Nahuys, P., 1866, Kort begrip der Christelijke religie, O.L. Schildkamp, Groningen.

Postma, D., 1875, Mijne handleiding voor de Godgeleerdheid volgens de kern van Aegidius Francken, Saul Soloman \& Co., Kaapstad.

Postma, P., 1909, 'De Theologische School', in J.L. Cachet (red.), Gedenkboek van het 50-jarig bestaan van der Gereformeerde Kerk van Zuid-Afrika, pp. 105-139, A.H. Koomans, Potchefstroom

Ras, J.L., 1981, Jan Lion Cachet as kerkman (186 -1912), ThD-proefskrif, PU vir CHO, Potchefstroom.

Schutte, G., 2009, 'Dirk Postma in herinnering', in J.M. Vorster (red.), Vit dankbaarheid: Die Gereformeerde Kerke in Suid-Afrika 1959-2009, pp. 3-14, V\&R Drukkery, Pretoria.

Snyman, G., 1992a, 'Kenteoretiese besinning oor teologiebeoefening aan die Teologiese Skool van Potchefstroom die afgelope twintig jaar', In die Skriflig 26(2), 247-266. https://doi.org/10.4102/ids.v26i2.1413

Snyman, G., 1992b, 'Binnegevegte in die GKSA: Verskuiwing van "plausibility structures"?', In die Skriflig 26(3), 351-367. https://doi.org/10.4102/ids.v26i3.1421

Snyman, W.J., 1956, Diktaat Hermeneutiek van die Nuwe Testament, Pro Rege Pers, Potchefstroom.

Van der Vyver, G.C.P., 1958, Professor Dirk Postma: 1818-1890, ThD-proefskrif, PU vir $\mathrm{CHO}$, Potchefstroom

Van der Vyver, G.C.P. (red.), 2006, My erfenis is vir my mooi, Potchefstroom Herald, Potchefstroom. 
Van der Walt, S.P. \& Du Toit, S., 1959, 'Die toekomstaak van die Gereformeerde Kerk', in S. du Toit, K.S. van Wyk de Vries, W.J. Snyman, H.J.J. Bingle \& D.W. Krüger.
(reds.), Die Gereformeerde Kerk in Suid-Afrika. 1859-1959, pp. 297-304, Dagbreek (reds.), Die Gereform

Van der Watt, J.G. (red.), 2012, Interliniêre Bybel: Grieks-Afrikaans. Nuwe Testament, Christelike Uitgewersmaatskappy, Vereeniging.

Van Deventer, H.J.M., 2009, Grammaties-historiese eksegese: Waarvandaan en waarheen?, Noordwes-Universiteit, Vaaldriehoek Geleentheidspublikasies, Vanderbijlpark.

Van Eeden, E.S. (red.), 2006, In U lig: Die PU vir CHO van selfstandigwording tot samesmelting: 1951-2004, Noord-Wes Universiteit, Potchefstroom.
Van Lieburg, F., 2014, 'Dynamics of Dutch Calvinism: Early modern programs for futher reformation', in G. van den Brink \& H.M. Höpfl (eds.), Calvinism and the making of the European mind: Studies in reformed theology, vol. 27, pp. 43-66, Brill, Leiden.

Venter, H. (red.), 1977, Totius: Versamelde werke, Band 1-11, Nasionale Boekdrukkery, Elsiesrivier.

Vergeer, W.C., 1993, 'Teologie en kenteorie: 'n Reaksie op die artikels van Gerrie Snyman', In die Skriflig 27(4), 563-582. https://doi.org/10.4102/ids.v27i4.1478

Vergeer, W.C. \& Du Plooy, J., 2008, Dagboek van Dirk Postma, WROS, Krugersdorp.

Vorster, J.M., 2004, Ethical perspectives on human rights, Potchefstroom Theological Publications, Potchefstroom. 